\title{
TESE SOBRE DIVERSIDADE, IDENTIDADE E GLOBALIZACIÓN
}

\author{
Héctor Díaz-Polanco
}

Universidad Nacional Autónoma de México 

Os eixes centrais deste texto son as relacións entre a pluralidade sociocultural e a sociedade globalizada. Como observou L. Grossberg, a globalización converteuse nunha noción sintomática do noso tempo, ata o punto de substituír a posmodernidade como o concepto preferido para concibir a especificidade da formación contemporánea. Por iso debato aquí a idea de que a globalización conduce a unha especie de homoxeneización cultural das sociedades. Esta conxectura, $\tan$ repetida nos últimos lustros que acadou certo viso de verdade incontestable, involucra diversos planos. Dous poden destacarse sobre os demais: que a globalización conduciría máis ou menos gradualmente á igualación das condicións socioeconómicas -equilibrio das circunstancias dos países empobrecidos, polo que fai ao benestar e a prosperidade, coas dos centrais ou desenvolvidos-, o que a longo prazo remataría coas desigualdades internas e coas asimetrías entre nacións; e que a globalización impulsa un sostido proceso de uniformidade cultural, por mor da hibridación, entre outros procesos, o que iría esfumando a diversidade que caracterizou ata o de agora as sociedades humanas.

Con respecto ao primeiro, o pensamento crítico recente destruíu o consello da globalización como axente da xeneralización do benestar económico e a equidade social, mostrando que, pola contra, a expansión sen precedentes do capital nas últimas décadas provocou un incremento da desigualdade e agravou as condicións de reprodución socioeconómica e ecolóxica no planeta, mesmo poñendo en perigo a mesma sustentabilidade humana. Esta demostración é tan contundente nas súas argumentacións e tan concienciuda nas súas probas fácticas que a tomaremos aquí para escusarnos de maiores argumentacións. Quizais as descarnadas palabras de J. K. Galbraith no sentido de que a globalización é a palabra inventada polo centro do Imperio «para disimular a nosa política de avance económico noutros países e para tornar respectables os movementos especulativos do capital» resumen unha convicción cada vez máis estendida e mellor fundada. 
O tópico da homoxeneización cultural tivo mellor fortuna, penetrando máis profundamente nas pregas do pensamento académico e do sentido común. Coido que tamén é discutible. A globalización non só non provoca a uniformidade cultural agardada ou anunciada, senón que complica o feito cultural e no seu seo rexistra un forte renacemento das identidades, acompañado de loitas reivindicativas no crecemento. Ben vistas as cousas, a globalización implicou mutacións nos fundamentos teórico-políticos do liberalismo que lle dá sustento, especialmente no tocante á pluralidade e no comportamento do capital fronte á diversidade, de modo tal que o sistema no seu conxunto desenvolveu na actual fase unha perspectiva e unhas prácticas, que se sintetizan no enfoque denominado multiculturalismo, precisamente orientadas a dar un tratamento axeitado á esfera cultural e os seus desafíos. A resultas diso, nesta fase globalizadora non só non se procura uniformar, como o gran desiderátum cultural do capitalismo, senón que se trata de aproveitar a diversidade en favor da consolidación do sistema e, especificamente, dos grandes negocios corporativos.

Ese é o marco dos retos aos que se enfrontan hoxe as identidades en todo o mundo. Non é que o sistema abandonase o propósito de someter coas súas leis a todas as sociedades. Pola contra, uniformar a dominación do capital é un impulso primixenio que se mantén invariable. Pero os capitáns do capital descubriron que a unidade do mundo baixo o seu dominio non pasa necesariamente pola uniformidade cultural á vella usanza -a do colonialismo e o imperialismo temperáns- e que a "valorización» da diversidade, segundo a lóxica de promover certa politización da cultura que provoca a despolitización da economía e a política mesma, favorece as súas metas.

\section{A HIPÓTESE DA HOMOXENEIZACIÓN CULTURAL}

Para dicilo en ton bíblico: no principio foi a globalización, e a globalización vaivos facer culturalmente homoxéneos, pero felices. Este foi o talante político-ideolóxico que prevaleceu hai uns lustros, durante a primeira fase do período que convencionalmente chamamos globalización. As confusións sobre o carácter dos cambios e as predicións frustradas verbo dos seus efectos sobre a diversidade están relacionadas coa caracterización de que é a globalización mesma, a versión pop. 
Agora sabémolo con algunha certeza: contrariamente ao previsto anos atrás, o chamado proceso de globalización vai acompañado dun notable renacemento das identidades en todo o mundo. O habitual é que a chamada batalla das identidades se libre en todos os recunchos cotiáns, en todas as pregas do sistema mundial. Ás veces, esta floración identitaria maniféstase baixo a forma de loitas culturais -nacionais, étnicas, relixiosas, rexionais-, con grande intensidade e a escalas variables ${ }^{1}$. Como, cada vez con máis frecuencia, os conflitos políticos, que xiran como remuíños impelidos desde abaixo polas disputas económicas e choques que teñen que ver co control dos territorios e os recursos, emerxen tinguidos de diferenzas socioculturais ou, cando menos, algúns dos seus protagonistas aparecen revestidos con roupaxes identitarias.

Un tras outro fóronse desbaratando os argumentos esgrimidos para anunciar un futuro de uniformidade que se consolidaría conforme a globalización desenvolvese a potencia unificadora e disolvente que lle atribuían. Por suposto, os ideólogos da globalización prometeron e anunciaron un mundo de igualación socioeconómica que iniciaría unha era de grandes transformacións cara a unha maior igualdade entre grupos, clases e nacións. Moi pronto advertimos que tamén neste eido o proceso ía dirixido exactamente en sentido contrario ${ }^{2}$. A «macdonaldización» do mundo que se anunciaba nun principio tampouco aparece xa no horizonte como un futuro contra o que non se podía loitar. Finalmente, os analistas máis disímiles enmarcados en tal perspectiva, a globalización como maquinaria homoxeneizadora, tiveron que sucumbir ante a evidencia de que, lonxe de decaer, os afáns identificadores se multiplican nunha escala nunca vista. Era precisamente o que se debía explicar. Xa no último tramo do século $\mathrm{XX}$, a perplexidade desencadeou o que foi percibido como unha explosión teórica arredor da noción de identidade.

\footnotetext{
${ }^{1}$ En calquera caso, todo indica que a globalización non é o ámbito máis propicio para a tranquila convivencia intercultural. Como advirte Bauman: «La globalización, según parece, tiene más éxito para reavivar la hostilidad intercomunitaria que para promover la coexistencia pacífica de las comunidades» (2003, p. 203).

2 Por exemplo, Vilas anotouno claramente: «Puede concluirse por lo tanto que la creencia en la virtualidad homogeneizadora de la globalización carece de fundamentos, y choca contra el desenvolvimiento efectivo del proceso. El aumento de las desigualdades a partir de las cuales las regiones y los países resultan incorporados a la etapa actual de la globalización, es una de las características de este proceso, a falta de factores que intervengan y que definan contratendencias eficaces» (1999, p. 83).
} 
Que foi o que fallou en tales previsións? A resposta pode atoparse na mesma idea da globalización daquela común. Dela derivaban os prognósticos sobre procesos, desexados ou temidos, de uniformidade cultural. Comezamos a entender que a actual universalización acciona baixo principios máis complicados. Ao parecer, como veremos, a globalización funciona máis ben como unha inmensa maquinaria de inclusión universal que busca crear un espazo liso, sen rugosidades, no que as identidades se poidan desprazar, articular e circular en condicións que sexan favorables para o capital globalizado. A globalización, daquela, intenta aproveitar a diversidade, aínda no transo globalizador buscará, por suposto, illar e eventualmente eliminar as identidades que non lle resultan domesticables ou dixeribles. A diversidade pode ser nutritiva para a globalización, descontando algún tipo de identidade que lle poida ser indixesta. A globalización, ao cabo, é esencialmente etnófaga.

\section{A CONSTRUCIÓN DE IDENTIDADES E A CRISE DA COMUNIDADE}

En efecto, o feito destacable dos últimos lustros é a importancia que acadou o tema das identidades. Referíndose a este fenómeno, Bauman observa que na actualidade "no hay al parecer ningún otro aspecto de la vida contemporánea que atraiga en la misma medida la atención de filósofos, científicos sociales y psicólogos». Non se trata dunha cuestión axustada ás preocupacións dos especialistas tradicionalmente dedicados a estas materias -os antropólogos, por exemplo-, senón dun foco que comeza a iluminar practicamente todos os recunchos das ciencias sociais, ata tal punto que «la "identidad" se ha convertido ahora en un prisma a través del cual se descubren, comprenden y examinan todos los demás aspectos de interés de la vida contemporánea. Las cuestiones establecidas del análisis social se están refiriendo y renovando para ajustarse al discurso que ahora gira en torno al eje de la "identidad" "(Bauman, 2001, p. 161). Non é doado determinar se isto está a acontecer para ben ou para mal do pensamento social; pero o que se pode dicir é que responde a pulsacións reais cuxa orixe é a máis recente fase capitalista, sen importar que a súa cristalización «societal» sexa caracterizada como sobremodernidade, tardomodernidade ou posmodernidade. 
Así pois, a rexeneración das identidades está indubidablemente vinculada coa actual fase de «mundialización» do capital; non é algo que acontece só a contracorrente da globalización, senón que se trata dun movemento impulsado dalgún modo pola súa ondada.

Agora ben, ás veces, a identidade de que se fala ten o efecto de ocultar procesos diferentes ou que se deberían distinguir. Podemos discernir polo menos dous, ambos como respostas ás novas condicións globalizadoras. Un, o vello reforzamento, renovado, arredor das comunidades que se defenden mediante o afianzamento das súas fronteiras e, cando é o caso, inventando mecanismos para manter e reproducir o grupo; outro, o que xorde tamén no marco da globalización, pero máis ben como a procura de saídas con sentido para escapar da crecente individualización e fragmentación que destrúe os tradicionais tecidos comunitarios, unha forza que sume os seus membros nunha carencia de normas socias insoportable. O primeiro intenta protexer a comunidade preexistente e, de ser posible, consolidala; o segundo, no medio das ruínas das colectividades, procura crear novas comunidades alí onde precisamente estas colapsaron, están a piques da desintegración ou os membros do grupo xa non atopan nelas seguridade e apoio para encarar os desafíos do contorno global: incerteza, precariedade, exclusión dos circuítos laborais, illamento, ansiedade e sensación de baleiro.

O problema que se advirte na análise de Bauman verbo da identidade radica precisamente en que reduce a cuestión ao segundo proceso; é dicir, non ten ollos máis que para as identidades como intento desesperado por construír comunidades nas novas condicións globalizadas, que resultan precisamente da destrución dos anteriores tecidos comunitarios e que rematan por ser en verdade os seus substitutos nesta etapa da sobremodernidade ou a posmodernidade. $\mathrm{O}$ autor destaca o laborioso traballo de trazar fronteiras como formas de darlles vida ás identidades. Aquí tamén se advirten en realidade dous tipos de procesos. Por unha parte, as fronteiras son trazadas ou reforzadas para delimitar e protexer comunidades tradicionais, progresivamente ameazadas polos efectos globalizadores. En xeral, este sería o caso dos pobos indíxenas e outros grupos identitarios. Por outra, o esforzo social opera ata certo punto en sentido contrario: aquí é a acción de trazar as fronteiras o que lle insufla vida e lle dá sentido á comunidade, co que, como destaca o autor en reforzo dos postulados de 
Frederick Barth, «as comunidades aparentemente compartidas, son subprodutos dun febril trazado de fronteiras. Despois de que os postos fronteirizos se atrincheiran, é cando se tecen os mitos da súa antigüidade e se tapan coidadosamente as recentes orixes político-culturais da identidade cos relatos da súa xénese».

Entrementres, pódese dicir que a construción de identidades no primeiro sentido é relativamente antiga e que se practicou en etapas anteriores á actual fase globalizadora. É aceptable afirmar que a construción de identidades no segundo sentido é peculiar da posmodernidade ou do exceso de modernidade, como resposta á individualización exacerbada que sofren as sociedades, particularmente, aínda que non só, no centro do sistema.

Colocado exclusivamente no tipo de construción de identidades que é distintivo da presente globalización, o autor advirte correctamente que é na actualidade, xustamente no momento en que hai cada vez menos comunidade e máis individualización, cando aparece con máis forza o fervor pola identidade. Así, «la identidad tiene que desmentir su origen, tiene que negar que no es más que un sustituto y más que nada evocar a un fantasma de la mismísima comunidad que ha venido a sustituir. La identidad brota en el cementerio de las comunidades, pero florece gracias a su promesa de resucitar a los muertos» (Bauman, 2001, p. 174). Como o autor só ve as reverberacións destas identidades, chega a unha conclusión que importa examinar. Refírome á súa inferencia no sentido de que as identidades que se están a construír «no son contrarias a la tendencia globalizadora ni se interponen en su camino: son un vástago legítimo y un compañero natural de la globalización y, lejos de detenerla, le engrasan las ruedas». A pregunta que hai que facer é se esta conclusión é aplicable ao primeiro tipo de construción de identidades, é dicir, aquela que busca fortificar e facer viables comunidades preexistentes, ancestrais, que operan cunha lóxica non só diferente á que impulsa a actual globalización, senón contraposta a esta. Neste caso, non se parte dunha perda do colectivo e unha individualización que, desde alí, procura crear ou imaxinar a comunidade substituta, senón dunha visión do mundo e unhas prácticas enraizadas no grupo que buscan engraxar os seus propios eixes comunitarios. 


\section{IDENTIDADE E IDENTIFICACIÓN}

O propio Bauman está incómodo cando utiliza indistintamente a palabra identidades para referirse a procesos tan disímiles, polo que suxire que se lle chame identificación ao fenómeno que intenta comprender. "Quizá en vez de hablar de identidades, heredadas o adquiridas, iría más acorde con las realidades de un mundo globalizador hablar de identificación, una actividad interminable, siempre incompleta, inacabada y abierta en la cual participamos todos, por necesidad o por elección». Teriamos así dúas palabras para procesos distintos: identidade e identificación. En que radica o específico da identidade e a identificación, respectivamente, na globalización da época posmoderna ou na perspectiva desenvolvida por Hardt e Negri, na fase do Imperio? En principio, é en relación coa identificación polo que se pode aseverar con firmeza que lle engraxa as rodas á globalización; así mesmo, é a que se pode caracterizar como «el efecto secundario y el subproducto de la combinación de las presiones globalizadoras e individualizadoras» (Bauman, 2001, p. 175). As identificacións, en moitos casos, son especies de identidades efémeras, líquidas.

Pola súa parte, a identidade foi cribada nas formas anteriores de «mundialización»; é un fenómeno anterior á globalización e non depende dela para a súa existencia, pois non é o seu directo produto ou subproduto. Aínda que a identidade, desde logo, xa non funciona completamente á marxe da globalización e sufriu os tremendos impactos que esta produce, aínda segue as mensaxes da súa lóxica propia, responde á voz da comunidade, e por iso se pode postular que non só non lle engraxa os eixes ao capital globalizador en todos os casos, senón que a súa existencia constitúe hoxe un dos maiores desafíos para este. De feito, a identidade mantense como unha esfera de resistencia singularmente molesta e exasperante para o capital. En troques, todo indica que a lóxica capitalista non só non se opón á identificación, senón que, dentro de certos límites, a promove.

$\mathrm{O}$ anterior non quere dicir que as identidades sexan inmunes ás novas presións globalizadoras. Aínda que na súa orixe as identidades non sexan produto da globalización, o seu destino está fortemente determinado polo desenvolvemento agresivo do neoliberalismo globalizador. Este ponlle límites á identidade e traballa para a súa integración subordinada ao novo dispositivo de dominación global ou para a súa disolución. Cando identidade se avén a ser reducida a unha 
cuestión cultural, que implica a renuncia a poñer sobre a mesa certas reivindicacións políticas, o sistema dálle paso franco á entrada no seu seo, á integración suave; pero se a identidade comporta a formulación dun conflito sociopolítico, e ademais económico, como o que contén o proxecto autonómico na súa versión, latinoamericana, non culturalista nin esencialista, daquela é seguro que será atacada a fondo. A cuestión é que, máis tarde ou máis cedo, moitas desas identidades son levadas a adoptar esta última tesitura. Así, o feito de que a identidade responda a unha voz diferente da do capital neoliberal, non a pon a salvo como unha fortaleza inexpugnable. Pola contra, como xa expliquei noutra parte, a lóxica e a diferenza conflitiva da identidade respecto ao neoliberalismo é, máis ben, a causa que alimenta un dos máis importantes dramas contemporáneos: a loita que establecen as fozas antagónicas da etnofaxia globalizadora e da resistencia autonomista.

Digamos de paso que os pobos indíxenas son empurrados a unha difícil escaramuza polas súas identidades, pois tamén se teñen que enfrontar ao efecto disolvente que provoca a globalización nas comunidades tradicionais. Falamos daquela aquí do que podemos chamar crise da comunidade. Este é un tema que se esquece decote, ou que só se menciona de paso, como se fose un asunto menor ou pasaxeiro. Debemos asumir que o querido obxecto de estudo antropolóxico atravesa por unha etapa crítica e perigosa. Sempre careceu de sustento histórico o tópico sobre a suposta condición de invencibles das comunidades indíxenas. A crise xeral da comunidade, inducida pola globalización, tamén está a alcanzar boa parte dos pobos indios en todas as partes. $\mathrm{O}$ renovado afán identitario dos indíxenas nas últimas datas ten moito que ver co feito de que esa crise tamén lles afectou, ás veces en partes vitais.

Un exemplo diso son os cambios drásticos en comunidades indíxenas de apreciables rexións de México, zarandeadas pola migración masiva da súa poboación e o consecuente abandono dos pobos, polo que fai que os membros produtivos sexan, así mesmo, as pezas claves para a reprodución de relacións e institucións medulares. Isto obriga, cara a dentro, a unha constante reconstrución da comunidade, o que non é de seu unha novidade, pero agora a unha escala, a un ritmo frenético e en condicións tan difíciles de manter baixo control, que colocan os conglomerados socioculturais nunha situación de especial fraxilidade e risco de quebra. $\mathrm{O}$ novo contexto obriga a recompoñer ou readap- 
tar os piares tradicionais da comunidade -como os sistemas de cargo tradicionais-, ao tempo que a estrutura comunitaria se apoia agora en novas pilastras, como é o caso das remesas dos seus emigrantes, un feito sen dúbida potenciado pola globalización, nunha medida antes totalmente descoñecida. Nos lugares de recepción, os inmigrantes buscan manter os vínculos coa comunidade orixinal; ou de plano procuran reconstruíla, en realidade reinventala, agora baixo condicións diferentes, a máis destacable das cales é o seu carácter «desterritorializado», ou mellor: a súa nova relación co territorio. O que todo isto indica é que a comunidade india está a cambiar aceleradamente e que se corresponde cada vez menos coa comunidade corporativa, homoxénea, pechada e en permanente equilibrio, que describiron antropólogos como Eric Wolf, mediando o século XX (Wolf, 1977). Se era dubidoso que tal comunidade existise daquela, hoxe, incuestionablemente, non é o horizonte en que os pobos lles deben dar vida ás súas identidades.

Volvendo ao noso, a diferenza da identidade, a identificación nace no seo do sistema globalizador e este non atopa moitas dificultades para integrala na súa lóxica. A identificación é un sucedáneo do colectivo, regularmente inocuo para o sistema globalizante e individualizador. Ao non superar a individualización, a identificación crea a ilusión dunha comunidade salvadora; ou, se se quere, crea unha comunidade no marco da lóxica global ou un conglomerado xa globalizado para calquera efecto. $\mathrm{O}$ sistema globalizado proporciona os elementos e as condicións que fan posible esa comunidade. De feito, os que tecen a identificación están realmente subsumidos na lóxica globalizadora da que queren escapar, e deste modo aliméntana. Quizais mesmo é a única fuga que lles está permitida: é un típico intento de escapatoria que, na medida en que se realiza en clave individualizada, se resolve nunha saída ilusoria. A identidade cosmopolita que emerxe diso resulta, en verdade, unha máscara da individualización. Mentres máis se empurra esta porta falsa, máis se afianza o edificio global; a cada volta de chave, queda asegurada máis a cancela. Este tipo de resistencia probablemente responde á sentenza: «o que resiste gaña». 


\section{IDENTIDADES MÚLTIPLES}

En primeiro lugar, cómpre superar as tentacións etnocéntricas e illantes que asexan a identidade. Seguramente existen varios camiños para logralo. Quizais un dos máis eficaces sexa asumir unha noción de identidade que rexeite todo suposto ou principio esencialista sobre as culturas. Isto implica convir en que, en cambio, as identidades son, ante todo, históricas. Confórmanse en contextos complexos que inclúen a presenza doutras culturas respecto das que se define a propia pertenza. $\mathrm{O}$ cambio destes contextos provoca transformacións identitarias, polo que as identidades non son inmunes ás transformacións «procesuales» de todo tipo. Neste sentido, cando un analista ignora as determinacións socioeconómicas, clasistas, etc., dunha identidade, cae nun erro. As identidades non se manteñen idénticas a si mesmas, por mor dunha pretendida esencia invariable que flota por riba da historia, senón que se fan e desfán, e ás veces entran en hibernación e posteriormente renacen.

En segundo lugar, as identidades son dinámicas, non só no sentido anterior de que nacen e poden perecer ou disolverse, senón ademais de que -mentres existen-cambian, se adaptan e realizan constantes axustes internos. A idea dunhas identidades que se manteñen estáticas, que conservan completamente os seus límites e son inmunes aos cambios internos, é unha ficción.

En terceiro lugar, hai que advertir que as identidades son internamente heteroxéneas. Os grupos identitarios non son entidades completamente homoxéneas, harmónicas ou estables, nin están exentas de tensións; por iso, teñen que resolver conflitos internos de maneira permanente. Existen subgrupos no seu seo e no seu ámbito que poden despregar diversas opcións, ás veces con algún grao de contradición entre si. $\mathrm{O}$ feito de que sexan internamente heteroxéneas é o que fai os sistemas identitarios campos para a autorreflexión e para a crítica, e non só para a adhesión; para a elección e o desacordo e non só para o consenso. Por iso, á hora de avaliar un sistema identitario como totalmente involuntario, habería que considerar a posibilidade de que a permanencia nel pasase por unha elección reflexiva, pola proba do desacordo e finalmente pola decisión voluntaria de manter a pertenza. É posible que no proceso en que se trata a facultade de axencia despregada para construír unha elección non se dea no caso de todos os suxeitos, nin sequera na maioría, pero o feito de que un 
pequeno grupo ou mesmo un só deles o realice proba o principal: que a comunidade identitaria é un campo de heteroxeneidade e contradición onde cabe a variedade de decisións.

En cuarto lugar, as identidades son múltiples. Especialmente cando falamos de grupos identitarios que foron incluídos ou inseridos en sociedades complexas -o que é a norma-, a identidade vívese «intersubxectivamente» -con todas as prevencións sobre o carácter figurativo que carga esta expresión (Jameson, 2004, p. 55) - como un complexo edificio de diferentes niveis. Cando os grupos deixaron de ser sociedades totais para formar parte de complexos societais maiores - por exemplo, o Estado-nación-, na actual fase de reestruturación dos Estados nacionais, e a entrada a un espazo de articulación no que o tempo tende a primar sobre o espazo -a territorialidade- as identidades múltiples tamén se consolidan ou expanden, facendo presión sobre as fronteiras previamente establecidas, redefiníndoas. Igualmente afectan o núcleo básico da identidade, que referiremos máis adiante. Esa é, pois, a condición da inmensa maioría das identidades contemporáneas, agás algúns pequenos casos no planeta.

Pódese dicir, xa que logo, que a identidade múltiple é a regra. Os suxeitos non se adscriben a unha identidade única, senón a unha multiplicidade de pertenzas que eles mesmos organizan dalgunha maneira no marco das obvias restricións sistémicas, pero que están presentes de modo simultáneo. $\mathrm{Na}$ súa mesma simplicidade, a imaxe de diversas camisetas convenientemente colocadas unha enriba da outra, sobre o mesmo suxeito, axuda a ilustrar o fenómeno ${ }^{3}$. Comprender a diversidade, neste caso, require considerar tal articulación complexa de planos identitarios, como constitutivos da noción social dos «nós». A pertenza identitaria inclúe estes diversos niveis ou capas, e é preciso que se estuden as súas mutuas influencias e contrapesos, e como todos eles contribúen a soster e dar sentido á chamada adscrición cultural.

Pero, finalmente, a multiplicidade de capas identitarias opera baixo un principio de xerarquía. Non todos os estratos que interveñen teñen, en cada caso e momento, o mesmo peso ou importancia subxectiva e, sobre todo, intersubxec-

\footnotetext{
3 O mesmo papel xoga a de caixas dentro de caixas como ilustración dos diversos planos e unidades da identidade. Geertz chamou á atención sobre «la amplia variedad de niveles» en que a heteroxeneidade cultural «existe y resulta efectiva» (2002, p. 257-258).
} 
tiva. Un ou algúns son colocados nun primeiro plano, e así determinan e organizan aos demais. Tal xerarquía, de feito, é un factor clave para definir a identidade de que se trata. Pero a xerarquización identitaria non é estática; é tamén dinámica. Xerarquías distintas poden operar en circunstancias diferentes: por exemplo, nun caso podemos poñer a énfase na pertenza étnica e noutro na de xénero; nunha situación apelaremos á filiación nacional e noutra á relixiosa, etc. Examinar estes mecanismos ordenadores é avanzar na comprensión das identidades. Pero tamén aforra moitos malentendidos. Como, por exemplo, cando un grupo indíxena proclama a súa identidade étnica, o que inmediatamente fai pensar aos sectores non indíxenas é que aquel carece por completo de identidade nacional. Non é raro que esta falsa avaliación conduza ao reproche social, e mesmo á represión, no nome dos valores nacionais ou outros que se consideran ausentes. A noción de identidade múltiple, completada co principio de xerarquización identitaria, permite comprender que unha particular adscrición cultural non implica forzosamente rexeitar outras pertenzas coas que seguramente se teñen moitos horizontes en común ${ }^{4}$. O Cortés non quita o Cuauhtémoc.

Non obstante, convén ter coidado, xa que en moitos casos se utiliza a noción de identidades múltiples non para ponderar a súa complexidade e profundidade, senón para limar as súas arestas e quitarlle importancia ao fenómeno identitario. $\mathrm{O}$ feito de que a identidade non sexa unívoca é interpretado decote como a proba de que toda invocación da identidade, en canto plataforma desde a que se reclaman certos dereitos, é un extremo inaceptable ou politicamente incorrecto, quer pola imposibilidade de definir as fronteiras identitarias, quer polo carácter secundario ou de pouco peso do ámbito invocado, dadas as mesturas culturais que sempre están presentes. Cómpre estar alerta contra a pretensión de utilizar a noción de identidades múltiples para desvalorizar a identidade mesma, colocándoa baixo a perspectiva da fluidez ou o hibridismo que en teoría relativizan o sentido de pertenza. Esta maneira de presentar as cousas é inadecuada.

\footnotetext{
${ }^{4}$ A xeito de exemplo, nun informe sobre identidade dos grupos étnicos nicaraguanos na Costa Atlántica, sinálase que as identidades múltiples son a regra, sen que iso implique un rexeitamento da afinidade nacional. Indica o estudo: «El $60 \%$ de los habitantes de la costa se siente tanto o más costeños que nicaragüenses. Esto no significa [...] que se promueva una negación de la identidad nicaragüense. Se trata más bien de un proceso condicional: un costeño no logra sentirse nicaragüense si antes no está bien establecida su identidad costeña» (Programa de Naciones Unidas para el Desarrollo, 2005).
} 
Desde logo, existen identidades múltiples deste tipo -as que procura xeneralizar a globalización capitalista- pero non son as únicas posibles.

As identidades múltiples que aquí interesan teñen sempre un núcleo duro, que procura sustentarse en cada caso no plano que proporciona maior apoio comunitario. A identidade básica asóciase á comunidade. Así, identidade e comunidade, ou mellor, "comunalidade» son fenómenos fortemente entrelazados. O sentido de pertenza, que lle outorga significado á vida, vai asociado á identidade que flúe da comunidade. Se a identificación globalizada, que examinou Bauman, «brota en el cementerio de las comunidades», aquí a forza cohesiva da identidade xermina no xardín da comunidade.

Cando todo sentido de comunidade desaparece, cando non é o sólido sostén de plano identitario ningún, as identidades múltiples debilítanse, dislócanse e entran en crise. As identidades múltiples transfórmanse daquela en identidades agónicas, en amasillo de referentes volátiles que poden ser facilmente manipuladas por políticos e mercadores, e poden terminar en identidades mortas. É o que está a acontecer con moitas sociedades golpeadas pola individualización do actual capitalismo globalizante, tal e como é descrito por diversos analistas. Como se observou, para os efectos deste tipo de crises non son inmunes os pobos indíxenas, se é que o plano que garantía o sentido de comunidade, colocado nun primeiro rango, resulta desarticulado e non poden atopar un substituto con idéntica consistencia. É daquela cando os indíxenas, atrapados no vórtice individualizador e anómico, entran, como acontece con outras vítimas da sobremodernidade, no paradoxal proceso de substituír a comunidade pola identidade, pero xa nun sentido completamente distinto: como a identificación que é a procura afanosa e inútil da comunidade perdida, talvez para sempre.

\section{AS CATRO HIPÓTESES SOBRE A GLOBALIZACIÓN}

En resumo, o anterior leva a formular catro hipóteses sobre a globalización: A primeira fúndase na inicial caracterización da globalización como unha forza inevitable e irrefreable, que non era froito de vontade ou proxecto político-económico ningúns, senón que emerxía dunha misteriosa necesidade. O TINA (There Is No Alternative) de Margaret Thatcher foi a súa formulación 
emblemática e arrogante. Esta interpretación converteuse no sentido común sobre a globalización. A súa difusión e aceptación públicas son o maior éxito político dos ideólogos globalizadores. Enmárcase no que Saxe-Fernández denominou a versión pop do paradigma globalista, que concibía a nova fase do capital nos termos dun impulso da natureza, case equivalente á lei da gravidade (Saxe-Fernández, 1999, p. 12; e Saxe-Fernández e Petras, 2001). O intelixente, recomendaban daquela os ideólogos neoliberais, era adaptarse a esta tendencia, pois non se podía facer nada para cambiala ${ }^{5}$. Nese marco nace a idea inicial de que a globalización conduciría a unha homoxeneización cultural tamén firme e inevitable. As identidades que se interpuxesen no seu camiño, por ser expresión do arcaico e dun mundo agonizante, serían arrasadas. Como xa vimos, esta é a hipótese que rapidamente sucumbe ante a evidencia.

A segunda advirte de que a globalización non lle afecta á diversidade do modo e cos ritmos antes supostos. As identidades poden atopar as fórmulas para manterse e mesmo para florecer no marco da globalización. Nuns casos, é unha visión reactiva á primeira tese, que sostén escuramente a súa certeza sen maiores argumentos que unha porfiada fe no carácter invencible das identidades. Noutros casos, albiscamos que o renacemento identitario é dalgunha maneira un rebote das contradicións inherentes á propia globalización 6 .

$\mathrm{Na}$ terceira, o afán de construír identidades non é menoscabado na globalización. Pero isto non só é o produto do proceso individualizador reforzado pola globalización; a construción de identidades, ademais, favorece ou vigoriza -engráxalle as rodas- o capital globalizante. É a perspectiva xa examinada que adopta Bauman. $\mathrm{O}$ que fai problemático este enfoque é a noción restritiva de identidade que asume o autor.

$\mathrm{O}$ cuarto enfoque que adopto aquí, asumindo en parte a perspectiva suxerida neste punto por Hardt e Negri ${ }^{7}$, sostén que a globalización -a condición de

${ }^{5}$ A contrapelo do que algunha vez recomendaba Bertold Brecht: «Non acepten o habitual como cousa natural [...]. Nada debe parecer natural. Nada debe parecer imposible de cambiar».

${ }^{6}$ Atópanse formulacións neste sentido, xa a fins dos anos noventa do século XX (Wallerstein, 1998; ou Giddens, 1999).

${ }^{7} \mathrm{O}$ enfoque que propoñen Hardt e Negri é diferente dos anteriores. En canto parten dunha caracterización máis detallada da natureza do sistema na actual fase do capitalismo -o imperio-, consideran varios momentos no tocante ao comportamento e os obxectivos da nova orde fronte ás identidades. Máis adiante examinaremos esta proposta. 
que non a confundamos só coa densificación das relacións socioeconómicas que contrae o proceso de mundialización, cos adiantos tecnolóxicos e outros fenómenos polo estilo; nin tampouco coa súa naturalización- non é un fenómeno homoxeneizador nos termos antes citados nin as identidades só engraxan o mecanismo globalizador. Hai construcións identitarias que lubrican o sistema -este é o núcleo de verdade que contén a análise de autores como Bauman-; pero outras botan area nas engrenaxes da globalización, semellan capaces de resistir con certo éxito ante a individualización posmoderna -como xa o fixeran coa moderna- e, aínda máis, iluminan horizontes a partir dos que se poden elaborar alternativas de emancipación fronte ao sistema neoliberal.

Non é fortuíto que unha boa parte dos ingredientes que alimentan os proxectos de rebeldía e emancipación, no amplo arco do actual "altermundismo», se inspire na diversa loita identitaria. No Foro Social Mundial, por exemplo, o eixe da diversidade, tanto na súa acepción propiamente cultural como social, política e biolóxica - defensa da biodiversidade-, ocupa un lugar cada vez máis medular nos debates e nas propostas reivindicativas. A razón disto é que en boa medida, actualmente, loitar contra a globalización neoliberal é loitar contra a individualización, non contra a individualidade, que é o destilado dos seus efectos devastadores e, como contrapartida, loitar a favor da preservación das diversas formas de comunidade humana e dos valores solidarios que estas colectividades conteñen. Neste sentido, podemos dicir que o total triunfo do capitalismo neoliberal implicaría o colapso das comunidades, ou unha situación moi próxima a isto; e que un feito dese alcance poría en perigo a sustentabilidade cultural e ecolóxica da humanidade.

\section{AS TRES ETAPAS DO DOMINIO IMPERIAL: A DIVERSIDADE NA GLOBALIZACIÓN}

As ciencias sociais deron un gran paso adiante nos últimos anos conforme inclúen, cada vez con máis énfase, o horizonte sociocultural, a diversidade e particularmente os fenómenos identitarios como parte da súa comprensión do mundo. Isto enriqueceu as súas perspectivas e os seus dispositivos analíticos. Pero cómpre revisar e corrixir constantemente os enfoques e as teses básicas, en consonancia co desenvolvemento do capitalismo, particularmente na súa actual 
fase globalizadora, para evitar lugares comúns que escurecen a percepción dos procesos en marcha.

Un deses tópicos, como xa se dixo, é a suposta concordancia entre a globalización do capital e a disolución da diversidade. Todo indica que a globalización vai acompañada dun notable florecemento das identidades. Isto, desde logo, ten que ver coa resistencia dos grupos identitarios, pero tamén coa propia lóxica globalizadora do capital. Para entendelo é preciso abandonar a perspectiva de que as cousas funcionan segundo os patróns homoxeneizadores de onte, e aceptar que a actual «mundialización» actúa con mecanismos máis complexos. Sen abandonar os propósitos integrantes do capital, a globalización procura agora a inclusión universal das identidades, sen que iso signifique en todos os casos a disolución das diferenzas.

En síntese, a globalización atopou a maneira de aproveitar a diversidade sociocultural no seu favor, saciando o sempiterno apetito do capital pola ganancia. Así, o capital globalizante e etnófago exalta a diversidade, mediante a ideoloxía multiculturalista, e como nunca antes procura converter a pluralidade de culturas nun puntal da súa reprodución e expansión.

Para iso, o sistema ataca as bases comunitarias das identidades e promove así mesmo as devanditas identificacións, que resultan especies de identidades individualizadas, sen sustento colectivo. Así e todo, as identidades con sólido fundamento comunitario, como os pobos indios latinoamericanos, seguen a ser unha cefalea para o sistema globalizador: opoñen unha resistencia tenaz e, ata o de agora, resultan pouco dixeribles polo capital. Neste terreo estase a dirimir a actual batalla das identidades.

En todo caso, o que parece certo é que a orde globalizadora, ou o Imperio, procura integrar no seu espazo non só a identificación, senón tamén a identidade. Todo debe ser inxerido e dixerido polo sistema. Para entender esta forza succionadora do Imperio, a súa voracidade insaciable e as estratexias de dominación para logralo, a obra de Hardt e Negri achega elementos suxestivos (Hardt e Negri, 2002). Ao meu ver, o principal é que mostra a complexidade do aparato globalizante, cuxa lóxica profunda non se centra na homoxeneización, polo menos se a entendemos á vella usanza do imperialismo cultural.

O devandito libro foi sometido a fortes críticas que son, ao meu ver, pertinentes no substancial (Borón, 2002; Borón, 2004; Petras, 2004; Negri e Zolo, 
2003). Máis adiante, na súa nova obra Multitude, os autores intentaron corrixir ou axustar as súas posicións, aínda que os puntos medulares que suscitaron as críticas se manteñen (Hardt e Negri, 2004) ${ }^{8}$. Non é o meu propósito determe aquí neste debate. Deixando a un lado construcións delirantes sobre o Imperio, propostas que lindan coa metafísica -a inabarcable multitude- ou o estraño misticismo do amor e a comunidade, semella que unha pasaxe de Imperio nos dá pistas sobre a complexa relación entre o capitalismo actual -polo de agora independentemente de que a esta fase lle chamemos imperialismo ou imperio- e a identidade - a diferenza, demarcada en canto modo de vida, como sostén Gray, e non só como a pluralidade de puntos de vista ou pluralidade de doutrinas comprensivas dos individuos nunha sociedade liberal, como o concibe Rawls (Rawls, 1995)99.

Hardt e Negri parten do principio central de que o aparato de dominio imperial actúa en tres etapas: unha inclusiva, outra diferencial e unha terceira, administrativa. En sentido estrito, non son fases dun proceso lineal; corresponden máis ben a momentos ou facetas do devandito dominio. Examinarei aquí as dúas primeiras.

A faceta inclusiva é a cara magnánima, liberal, do Imperio, na que este se presenta como cego ás diferenzas e imparcial. Procura lograr «la inclusión universal dejando de lado las diferencias inflexibles o inmanejables que, por lo tanto, podrían dar lugar a conflictos sociales». Para iso, é preciso que considere as diferenzas como non esenciais ou que ignore a súa existencia. $\mathrm{O}$ veo da ignorancia permite a aceptación universal que, así mesmo, fai posible o consenso coincidente. Así, extírpase o potencial contestatario das diversas subxectividades, e o

\footnotetext{
${ }^{8}$ Bensaid, por exemplo, sinala a propósito desta obra: «Algunas extrapolaciones que aparecían en Imperio, pronto desmentidas por las expediciones imperialistas y por la hegemonía militar restaurada del Estado nacional estadounidense, han sido corregidas y matizadas en Multitud. Pero en la medida en que se mantiene la hipótesis de un mundo rizomático, acentrado y acéfalo, el poder efectivo (del capital, del Estado, de la fuerza) tiende a disolverse en los "efectos del poder" y en los juegos del anti-poder. Una estrategia sin espacio propio, sin objetivo, sin dialéctica de fines y medios, resulta difícil de pensar» (2005, p. 14). Véxanse tamén Guillermo Almeyra (2005) e Jorge Luis Cerletti (2005).

${ }^{9}$ Gray expresa: «En recientes escritos liberales, el hecho pluralista se refiere a una diversidad de ideales personales cuyo lugar está en el ámbito de la asociación voluntaria [...]. Pero el hecho pluralista no es la verdad trivial y banal de que los individuos mantienen diferentes ideales personales. Es la coexistencia de diferentes modos de vida. El pensamiento liberal convencional consigue confundir este hecho porque da por sentado que existe un consenso sobre los valores liberales» (2001, p. 21).
} 
espazo público de neutralidade do poder que resulta permite establecer e lexitimar unha noción universal de xustiza que constitúe a medula do Imperio ${ }^{10}$.

Resulta evidente que os autores están a utilizar os referentes rawlsianos para debuxar os contornos do Imperio no tocante ao seu afán de inclusión, de construír consenso liberal. Para conseguir isto, nada como soster que é posible establecer os principios universais da organización sociopolítica con independencia da diversidade básica da sociedade. É a contribución central de Rawls nas súas dúas obras seminais. Posto que é esa mesma diversidade a que impediría chegar a acordos que sexan válidos para todos -universais-, o procedemento que propón Rawls, como é sabido, inclúe o veo da ignorancia nunha posición orixinal, na que as partes buscan definir os fundamentos do contrato social, que non é máis que un intento radical de excluír a diversidade como un principio -o metaprincipio- esencial da teoría da xustiza (Rawls, 1995, p. 17-26). Con outras palabras: é como se acada que o sistema liberal se sustente en principios que non inclúen a pluralidade, mentres se garante que as identidades non opoñan resistencia. Así poden alcanzar o "consenso traslapado» ${ }^{11}$, prometendo que, no tocante ás distintas concepcións da vida en competencia, o poder será neutral, é dicir, cego á diferenza. Tal neutralidade, ou indiferenza fronte á diferenza, é a clave da nova teoría da xustiza que achega Rawls á fase imperial do sistema. O Imperio obtén un fundamento universal que é a base do seu carácter inclusivo e favorece a súa estabilidade ${ }^{12}$.

\section{O PROCESO ETNOFÁXICO}

A outra imaxe forte dos autores é que, practicando a indiferenza aos diferentes para deixar de lado as súas particularidades, o sistema funciona como unha

\footnotetext{
${ }^{10}$ A lóxica da indiferenza, a neutralidade e a inclusión conforma «un fundamento universal» que aplica a todos sen excepción. "En este primer momento, el imperio es pues una maquinaria de integración universal, una boca abierta con un apetito infinito que invita a todos a ingresar pacíficamente en sus dominios». O imperio non busca excluír as diferenzas; actuando "como un potente vórtice», incita os outros «a penetrar en su orden». Deste xeito, o imperio busca converterse "en una especie de espacio uniforme, a través del cual las subjetividades se deslizan sin oponer resistencia ni presentar conflictos sustanciales» (Hardt e Negri, 2002, p. 187 e 188); as cursivas son nosas.

${ }^{11}$ Sobre a idea de "consenso traslapado" ver J. Rawls (1995).

${ }^{12}$ Analicei con máis detalle esta formulación rawlsiana e as súas consecuencias (Díaz-Polanco, 2006).
} 
poderosa maquinaria de integración total, un potente vórtice cuxa característica máis notable é o seu apetito insaciable. A idea do Imperio como voraz boca aberta é unha figura inspiradora. A principios dos noventa intentei entender este proceso a escala do Estado-nación latinoamericano mediante o concepto de etnofaxia, que na súa formulación incluía imaxes similares: apetito de diversidade, dixerir ou asimilar o comunitario, engulir ou devorar o outro, etc. Fronte ás accións brutais do pasado -xenocidio, etnocidio-, agora a etnofaxia tomaba corpo como un conxunto de sutís forzas disolventes do sistema. Asumindo como un norte a noción de etnofaxia proposta, realizáronse en anos posteriores interesantes estudos de casos de tales procesos ${ }^{13}$.

En efecto, nunha obra de 1991, advertín que as prácticas cruamente etnocidas resultaban xa inconvenientes, polo que se estaba pasando "a una compleja estrategia que propongo denominar etnófaga», é dicir, o abandono dos programas e as accións explicitamente encamiñados a destruír a cultura dos grupos étnicos e á adopción dun proxecto de máis amplo alcance que aposta polo efecto absorbente e asimilador das múltiples forzas que pon en xogo o sistema. Non era o abandono da meta integrante, senón a súa promoción por outros medios. «La etnofagia -dicía- expresa entonces el proceso global mediante el cual la cultura de la dominación busca engullir o devorar a las múltiples culturas populares, principalmente en virtud de la fuerza de gravitación que los patrones nacionales ejercen sobre las comunidades étnicas».

Non se pretende a destrución mediante a negación absoluta ou o ataque violento das outras identidades, senón a súa disolución gradual mediante a atracción, a sedución e a transformación. Polo tanto, a nova política é cada vez menos a suma das accións persecutorias e dos ataques directos á diferenza, e cada vez máis o conxunto dos imáns socioculturais e económicos despregados para atraer, desarticular e disolver os grupos diferentes. En síntese, "la etnofagia es una lógica de integración y absorción que corresponde a una fase específica de las relaciones interétnicas [...] y que, en su globalidad, supone un método cualitativamente diferente para asimilar y devorar a las otras identidades étnicas».

13 Cfr., por exemplo, sobre Ecuador, Víctor Bretón Solo de Zaldívar (2001, 2002); e sobre Bolivia, Félix Patzi (1999, p. 535-559). 
Cando menos, a etnofaxia implica dous cambios importantes. En primeiro lugar, o proxecto etnófago é levado adiante mentres o poder «manifiesta respeto $\mathrm{o}$ indiferencia frente a la diversidad, o incluso mientras exalta los valores indígenas». Nesta circunstancia, o Estado pode presentarse como o garante ou o defensor dos valores étnicos, especialmente cando a súa política debe atenuar os efectos dos brutais procedementos do capitalismo salvaxe ou tropeza cos groseiros métodos etnocidas de sectores recalcitrantes que non comprenden as sutilezas da etnofaxgia. O certo é que no tempo da etnofaxia, a protección estatal das culturas indias alcanza o seu máximo carácter diversionista.

Non obstante, alenta a participación, as políticas participativas tan de moda a partir dos oitenta, dos membros dos grupos étnicos, procurando que un número cada vez maior destes se convertan en promotores da integración pola súa propia vontade. Os dirixentes indios non os preparan para que sexan intelectuais indíxenas, senón ideólogos e axentes das novas prácticas indixenistas. É unha estratexia que actúa coa táctica da quinta columna (Díaz-Polanco, 1991, p. 96-98).

Desde logo, non se falaba naquel momento de exclusividade dos procedementos etnófagos, senón de preponderancia, como parte dunha manobra de envolvemento e asimilación, con ritmos e niveis de desenvolvemento diferentes segundo os países. O que se chamou no debate latinoamericano etnicismo ou etnopopulismo, que acadou a súa máxima repercusión nos anos oitenta do século XX, estaba axustado xa ao ciclo da etnofaxia. O poder estaba cómodo co discurso etnicista -especie de precursor crioulo do multiculturalismo na rexiónque defendía a diversidade étnica e rexeitaba a acción concertada dos indios con outras clases ou sectores subordinados non indíxenas e, apoiándose nunha peculiar concepción do colonialismo, repudiaba a revolución á maneira occidental, xusto porque esta poñía énfase na loita de clases, que en teoría non tiña nada que ver cos indíxenas, o que na práctica terminaba sendo unha renuncia a toda rebelión contra o sistema ${ }^{14}$.

\footnotetext{
${ }^{14}$ Digamos de paso que, recentemente, referíndose a esta corrente de pensamento sobre as relacións coloniais, Eagleton lembrou que «parte de la nueva teoría entendía de sí misma que desplazaba su atención de la clase al colonialismo; ;como si el colonialismo y el poscolonialismo no fueran en sí mismos cuestiones de clase! A su modo eurocéntrico, identificaba el conflicto de clase solo con Occidente, o lo entendía solo en términos nacionales» (2005, p. 23).
} 
Anos despois, subliñamos que a etnofaxia xurdía nun marco de notable ascenso político dos pobos indios, unha de cuxas cimas foi o levantamento zapatista de 1994, o que inquietaba o poder. A razón disto radicaba en que a articulación das demandas indíxenas mostraba arestas políticas cada vez máis acusadas. A redución culturalista das identidades naufragaba. Iso explicaba que os gobernos ensaiasen iniciativas cuxas orientacións eran, en aparencia, contraditorias: "por una parte, impulsan enmiendas legales para reconocer el carácter pluricultural de la sociedad; y por otra, adoptan modelos socioeconómicos que minan la identidad étnica de los pueblos indios. Es lo que puede llamarse la estrategia del indigenismo etnófago. Esto es, mientras se reconoce la vigencia de las identidades, se busca engullirlas, socavarlas desde sus cimientos: desde la misma comunidad». A idea era que ningún recoñecemento lle afectase á orde política, o novo poder conservador, ou ao modelo económico, o neoliberalismo aínda embrionario, que impoñía a globalización como unha necesidade ${ }^{15}$.

$\mathrm{Xa}$ era claro que os pobos estaban fronte a desafíos novos nun contexto tamén novo. As ameazas ás identidades estaban agora na «fase terminal de la modernidad (preludio de la anunciada posmodernidad)", e resultaban dunha «globalización que, de hecho, pretende ignorar las particularidades, la pluralidad étnica y las maneras distintas de vivir", pero mediante outros procedementos. Os ataques non seguían modelos anteriores, aos que as comunidades "podrían sobreponerse con estrategias ya probadas». As forzas ás que se enfronta a organización comunal son enormemente máis poderosas e eficaces na actualidade ca no pasado: a nova estratexia «es más pertinaz y potente en la misma medida en que busca socavar la unidad comunal desde adentro, poniendo más activamente en juego las fuerzas individualistas del mercado, y utilizando pautas y mecanis-

15 «En el marco de la estrategia en cuestión incluso cabe cierto reconocimiento de "derechos”, siempre que ello no implique transformaciones políticas por lo que hace a la distribución del poder y a la organización del Estado ni cambios en el modelo económico (neoliberal) que, según se alega, es "impuesto" por los imperativos de la globalización. Mientras tanto, si la comunidad como sustento primario de la etnicidad puede ser debilitada, ninguna territorialidad podrá cargarse de contenidos culturales, socioeconómicos y políticos. En algunos casos, como lo ilustra el actual proceso mexicano [...], se ataca directamente el fundamento de la cohesión comunal, guardando la debida reverencia a lo pluricultural» (Díaz-Polanco, 1997, p. 18-19). 
mos de atracción y seducción que excluyen (o reducen al mínimo necesario) los brutales o burdos medios de otras épocas» ${ }^{16}$.

Aínda que observabamos todo isto desde o balcón da experiencia mexicana, agoirabamos que o que se incubaba neste país transcendía as súas fronteiras, pois só anticipaba o sentido das novas políticas que terían que enfrontar os pobos indios en todas as partes (Díaz-Polanco, 1997, p. 31).

Existen notables similitudes entre a análise de Hardt e Negri sobre este aspecto do aparato de control imperial e a etnofaxia que propoñiamos para entender as novas formas de dominio sobre as etnias latinoamericanas. Tamén existe unha diferenza crucial polo que fai ao seu alcance respectivo. Aínda que albiscabamos que a nova estratexia estaba relacionada coa globalización e o modelo neoliberal e que transcendía os espazos nacionais, basicamente a etnofaxia interpretaba os procesos atinentes aos grupos étnicos e a énfase estaba posta nunha rexión determinada. Os autores de Imperio mostran que a etnofaxia non alcanza só os grupos étnicos indios, senón tamén todas as diferenzas ou identidades que son atraídas cara a unha orde imperial; así mesmo, a etnofaxia non se circunscribe a un ámbito restrinxido ${ }^{17}$.

Así pois, o concepto adquire maior densidade ao ampliar o proceso etnofáxico ao ámbito global, como un imperativo sistémico. Non se trata dunha faceta ou un momento do despregamento neoliberal en Latinoamérica, localizado e continxente, senón dun dispositivo clave do dominio imperial no seu conxunto. A etnofaxia non é só local, senón primordialmente global. Ou, mellor dito, a súa forma de actuación no local só se pode comprender considerando a súa lóxica global ou «glocal». Ao fundamento universal que proporciona o chamado liberalismo igualitario rawlsiano e á súa xustiza como equidade ou imparcialidade

\footnotetext{
${ }^{16}$ Enseguida agregaba: «Los que corren no son los mejores tiempos para la comunidad. Toda forma de organización en la que se utilizan procedimientos colectivos para la toma de decisiones, se ejerce la autoridad como servicio, funcionan los controles internos de los recursos, se practica la reciprocidad, etcétera, es vista con sospecha y sobresalto por los profetas de la globalización neoliberal. Por ello, la comunidad comienza a ser atacada ferozmente en América Latina. No debe llamar a engaño el discurso que, simultáneamente, canta loas a la pluralidad y a las identidades étnicas: esto forma parte de las maniobras de diversión que son inherentes a la nueva estrategia etnófaga» (Díaz-Polanco, 1997, p. 25 e 26).

${ }^{17} \mathrm{O}$ que se corresponde coa súa idea de que na «sociedad imperial, la producción de la subjetividad tiende a no estar limitada a ningún lugar específico» e a súa lóxica de transformación «tiende a generalizarse, en diferentes grados, en todo el mundo» (Hardt e Negri, 2002, p. 186 e 187).
} 
correspóndelle a maquinaria de integración universal, a ávida boca aberta do Imperio, a etnofaxia universal.

Pero a etnofaxia universal non pode actuar sen un enfoque de afirmación da diversidade, de exaltación da diferenza, de sedución do Outro e, particularmente, sen unha teoría que precise das condicións e prerrequisitos en que as identidades poden ser aceptadas, é dicir, os límites da tolerancia neoliberal cara ao diferente. Ambas as cousas son ofrecidas polo multiculturalismo.

\section{O MOMENTO MULTICULTURALISTA}

A etnofaxia universal, en efecto, require dunha segunda fase: o momento diferencial. Sen el a etnofaxia, en canto control imperial, sería unha pura homoxeneización sociocultural, de fronte a unha externalidade para colonizar, á vella usanza do colonialismo ou do colonialismo interno. $\mathrm{Na}$ época da etnofaxia, as diferenzas están dentro do sistema, e cada vez máis son o propio capital globalizado, particularmente as grandes corporacións, e os organismos globais son os que se ocupan das identidades, e cada vez menos o Estado-nación fronte ás colonias externas ou internas. Neste sentido apunta o enfoque de Žižek cando fala de «autocolonización», pois "ya no nos hallamos frente a la oposición estándar entre metrópolis y países colonizados» dado que, nun xiro non exento de certa xustiza poética, a empresa global de hoxe tamén "trata a su país de origen simplemente como otro territorio que debe ser colonizado». Así, «el poder colonizador no proviene más del Estado-nación, sino que surge directamente de las empresas globales» (Žižek, 1998, p. 171).

Esta perspectiva debe asumirse como unha tendencia en desenvolvemento, que se expande mediante unha nova palpitación do sistema, o que non implica aceptar, como parece crer Žižek, que xa non actúan nos países colonizadores; isto sería desmentido polas recentes ocupacións colonizadoras de Afganistán e Iraq. Resulta evidente que as empresas e as institucións globais teñan que acudir aínda aos servizos dos Estados para realizar os seus propósitos de integración ao capital universalizado.

Tampouco a época etnofáxica implica que desaparezan os mecanismos de colonialismo interno. Seguen a actuar, agora baixo formas actualizadas, precisa- 
mente alí onde as identidades se mostran reticentes a integrarse baixo as condicións do capital globalizante ou resisten ante as vellas e novas formas de asimilación. Grupos identitarios, como é o caso notable dos pobos indíxenas latinoamericanos, obrigan a que o poder do capital responda con ameazas e procedementos represivos que configuran a nova forma dun colonialismo interno adaptado ás condicións da actual fase globalizante. Neste sentido, a noción de «intracolonialismo» utilizada por González Casanova, agora articulada con outras formas posmodernas de control internacional e transnacional, segue a ser útil para entender a complexidade da situación actual ${ }^{18}$.

De feito, ben entendido, o que manifesta o multiculturalismo como ideoloxía do capitalismo global é a propensión deste a xeneralizar o colonialismo interno, igual que a globalización procura universalizar a etnofaxia. Isto despréndese mesmo da formulación de Žižek, cando afirma que o multiculturalismo expresa a autocolonización capitalista global, do mesmo xeito que en fases anteriores o imperialismo cultural occidental expresaba o colonialismo imperialista. $\mathrm{O}$ novo, pois, é que, a diferenza do vello imperialismo cultural, o multiculturalismo «trata a cada cultura local como el colonizador trata al pueblo colonizado: como nativos, cuya mayoría debe ser estudiada y respetada cuidadosamente» (Žižek, 1198, p. 172). Este respecto, non obstante, ten un límite; e cando a cultura da que se trata non acepta a tolerancia multiculturalista, daquela póñense en práctica métodos que reciclan as vellas fórmulas do colonialismo interno.

Pero, en todo caso, agora o control imperial quere ir alén de etapas anteriores. Segundo Hardt e Negri, o momento diferencial «implica la afirmación de diferencias aceptadas dentro del espacio del imperio». Mentres que desde o punto de vista da teoría da xustiza imperial, o sistema debe mostrarse neutral e indiferente fronte ás diferenzas, en cambio «desde el punto de vista cultural, las diferencias se exaltan. Puesto que ahora se consideran culturales y contingentes,

18 «En medio de los grandes cambios ocurridos desde el triunfo global del capitalismo, el colonialismo interno, o intracolonialismo, y su relación con el colonialismo internacional, formal e informal, y con el trasnacional, es una categoría compleja que se reestructura en sus relaciones con las demás, y que reclama ser considerada en cualquier análisis crítico del mundo que se inicie desde lo local o lo global» (González Casanova, 2003). Comparto a opinión do autor no sentido en que «hoy resultaría del todo falso un análisis crítico y alternativo de la situación mundial o nacional que no incluya al colonialismo interno articulado al internacional y al transnacional» (González Casanova, 2003). 
antes que biológicas y esenciales, se supone que tales diferencias no afectan la franja central de esa condición común o ese consenso coincidente que caracterizan el mecanismo inclusivo del imperio». Non obstante, en contra do que pensan algúns autores, Hardt e Negri observan que, como norma, «el imperio no crea diferencia. Toma lo que ya existe y lo utiliza a su favor» ${ }^{19}$.

A idea de que hai interese en crear diferenza no seo do sistema global, cuxos signos serían o enfoque e as políticas multiculturalistas, é froito das confusións temerosas que aniñan nas almas neoconservadoras. Un exemplo diso son as posicións defendidas por G. Sartori. Expoñente dun liberalismo anticuado neste punto, Sartori é arquetipo da maneira de ver o multiculturalismo como un proxecto de teórica promoción das diferenzas culturais. Na súa escasa comprensión do multiculturalismo e do papel que este cumpre na fase actual do capitalismo, chega a cualificalo como un plan antiliberal e unha especie de intento da esquerda de socavar o liberalismo. Ao seu ver, as democracias liberais deben pechar as portas a identidades perigosas, como é o caso das culturas de raizame musulmá (Sartori, 2001) ${ }^{20}$. Sartori representa unha crítica do multiculturalismo desde a dereita liberal, que non o ve como un dispositivo da globalización do capital, senón como unha concesión innecesaria e arriscada, como un erro de Occidente.

\footnotetext{
${ }^{19}$ É dicir, existen «diferencias no conflictivas, el tipo de diferencias que, cuando es necesario, pueden dejarse de lado [...]. Se imagina que tales diferencias son culturales antes que políticas pues se supone que no habrán de conducir a conflictos incontrolables, sino que, en cambio, habrán de funcionar como una fuerza de pacífica identificación regional». Os autores exemplifican coa recreación de identidades étnicas nos países socialistas e ex-socialistas, bendicida polos Estados Unidos e os organismos globais, pois certas diferenzas considéranse compoñentes valiosos da transición ao capitalismo. Igualmente, «en los Estados Unidos, muchas promociones oficiales del multiculturalismo implican la glorificación de las diferencias étnicas y culturales tradicionales bajo el paraguas de la inclusión universal» (Hardt e Negri, 2002, p. 188); as cursivas son nosas.

${ }^{20} \mathrm{Na}$ atmosfera da histeria antiislámica provocada polos ataques terroristas do 11 de setembro de 2001, o enfoque de Sartori cobrou notoriedade na franxa máis conservadora de Occidente. É a forma máis frecuente de expresarse hoxe a ortodoxia liberal, particularmente nun perfil ultraconservador. Nun discurso pronunciado en Madrid en xullo de 2005, no que combateu o multiculturalismo, José María Aznar dixo que Giovanni Sartori describira perfectamente as diferenzas entre o pluralismo e o multiculturalismo: o pluralismo é o respecto pola liberdade individual, as leis de todos e os valores compartidos. O multiculturalismo é un risco que pode dar paso con facilidade ao enfrontamento e que permite a desigualdade.
} 


\section{UNHA PARÉNTESE ILUSTRATIVA: O MARKETING MULTICULTURAL}

Antes de entrar no núcleo central desta fase diferencial (o multiculturalismo), detereime un momento para ilustrar este «tomar o que existe» cun típico sintoma da globalización: o marketing multicultural das grandes corporacións. É probablemente unha das expresións máis visibles da actuación etnofáxica. Co marketing multicultural, a etnofaxia, como prácticas de asimilación e engulido das identidades, quizais sobre todo na forma que Bauman denominou «identificación» e o multiculturalismo, como visión positiva da diversidade e exaltación da tolerancia na era neoliberal, atópanse e abrázanse nun reforzamento mutuo.

O desiderátum das grandes corporacións non é crear diversidade, senón integrala nas súas metas en canto maquinarias produtoras de ganancias. Isto reflíctese na fogosa actividade para darlles un toque multiculturalista ás empresas e engadir un enfoque pluricultural ás súas estratexias de negocios. Nos últimos anos, un número crecente de grandes empresas declaráronse multiculturalistas e axustan a súa imaxe, a súa organización e as súas técnicas de mercado aos imperativos da diversidade. Ningunha corporación quere parecer unha compañía desarraigada, sen vínculo co medio cultural, polo que, por exemplo, o HSBC se anuncia como o banco local do mundo. O global semella descubrir a vantaxe do localizado; ou, mellor dito, a verdadeira mensaxe é que, cada vez máis, todo o positivamente local terá que ser global, ou "glocal». A comezos de 2005, o First Intercontinental Bank declarouse como un banco multicultural, preocupado polo progreso dunha sociedade que é cada vez máis diversa. En canto entidade multicultural interesada en respectar o idioma e a cultura dos seus clientes, integra unha nómina de varias nacionalidades e culturas. En maio, a Hilton Hotels Corporation estende o seu alcance multicultural: crea un consello asesor multicultural cuxa tarefa é recomendar as prácticas e os estándares de negocios dirixidos cara a mercados multiculturales, como o afroamericano e o hispano. E así polo estilo ${ }^{21}$.

\footnotetext{
${ }^{21}$ Estimuladas pola nova atmosfera, empresas máis modestas non se quedan atrás e pregoan con gran pompa o seu carácter multicultural: a mediados de 2005, un hotel de Madrid, o Puerta América, construído coa participación de deseñadores de varias nacionalidades, presentouse como o primeiro hotel multicultural do mundo, e o negocio hispano-latino Zócalo Mall anunciouse como o primeiro centro comercial multicultural de Arizona.
} 
Esta orientación segue a tendencia observada nos últimos anos pola Association of National Advertisers (ANA) dos Estados Unidos. No seu segundo estudo sobre o tema, publicado a finais de 2004, a ANA rexistra que as empresas de marketing e publicidade son máis conscientes sobre a urxencia de incluír unha política multicultural na súa xestión. A razón é que as firmas ás que serven entenderon que deben conseguir novos clientes e integrarse en novos mercados multiculturais, posto que a sociedade se volveu multicultural. Isto deu orixe a dúas novidades no marco dos grandes negocios globalizados: a creación de novos departamentos de marketing multicultural nas empresas, como o fixeron Unilever e Kodak, entre as pioneiras nese eido, e a aparición da chamada publicidade multicultural, cuxa actividade principal será nada menos que a elaboración de análises transculturais do consumidor.

Como parte desta excitación multiculturalista das corporacións, por exemplo, organizaron diversos cumios de mercado étnico e multicultural, coa participación de expertos de poderosas empresas que tratan de desentrañar os segredos do mercado baseado nas crenzas. Para ter unha idea do carácter deste conclave, abonda con dicir que entre os que comparten as súas estratexias hai expertos de empresas como Avon, Kraft, McDonald's, Ford, Nike, Citibank NA, Comerica Bank, Nickelodeon, Lufthansa, MTV World e Oxford Health Plans ${ }^{22}$.

En casos notables, como a multinacional Verizon Communications, a atención á diversidade converteuse nun factor clave para o desenvolvemento e o éxito comercial da empresa. A compañía ten a súa vista posta en mercados en crecemento que, nos Estados Unidos, inclúe os afroamericanos, os asiáticos e os hispanos. Tan só este grupo minoritario ten un poder adquisitivo de 686000 millóns de dólares anuais, segundo o cálculo da empresa. Verizon aplica, desde logo, unha estratexia de marketing ampla e multicultural. Pero unha característica distintiva desta corporación é que usa a diversidade como unha enerxía, non só para acrecentar o seu poder no mercado, senón tamén para vigorizarse internamente. $\mathrm{O}$ seu ámbito de acción comprende os asiáticos e surasiáticos, discapacitados, con preferencias sexuais diferentes como gais, lesbianas, bisexuais e transgender, hispanos, xudeus, nativos americanos, veteranos e mulleres.

22 Cfr. PRNewswire (7/9/2005); axencia International News e Strategic Research Institute (http://www.srinstitute.com). 
Definitivamente, esta corporación non comparte as aprehensións de Sartori sobre os supostos obxectivos antiliberais e os efectos negativos do multiculturalismo. Ao contrario, en Verizon advirten unha visión perspicaz sobre as vantaxes do multiculturalismo para os negocios globais. Así o din abertamente os seus voceiros: fixemos da diversidade unha parte integral do noso negocio. Así mesmo, a empresa non se reprime á hora de definir o que abarca a diversidade; máis ben está ansiosa por aproximar a diferenza, en toda a súa exuberancia, ás súas fauces: A nosa definición da diversidade comprende a gama enteira de diferenzas humanas, incluíndo idade, pertenza étnica, educación, orientación sexual, estilo do traballo, raza, xénero e demais ${ }^{23}$.

Pero non nos debe enganar esta devoción corporativa polas diferenzas. Como lembrou Bensaid, o que aquí se presenta como defensa da diferenza queda reducido «a una tolerancia liberal permisiva que es el reverso consumista de la homogeneización mercantil». As diferenzas conflitivas «se diluyen entonces en lo que ya Hegel llamaba una diversidad sin diferencia: una constelación de singularidades indiferentes». Certo discurso posmoderno construíu unha retórica do desexo na que o suxeito vive unha sucesión de identidades sen historia, desconectada da lóxica das necesidades sociais ${ }^{24}$.

\section{O MULTICULTURALISMO REALMENTE EXISTENTE}

Con este pano de fondo, pasemos agora unha concisa revista ao multiculturalismo como enfoque ou tratamento da diversidade. $\mathrm{O}$ multiculturalismo beneficiouse da súa propia polisemia, das súas múltiples máscaras. En efecto, o que hoxe se designa con esa palabra oculta diversos significados, mesturados nun conveniente cóctel ideolóxico.

${ }^{23}$ Cfr. http://multimedia.verizon.com/diversity/.

24 «No es para nada sorprendente que este discurso haya tenido una buena acogida [...], puesto que la fluidez reivindicada por el sujeto está perfectamente adaptada al flujo incesante de los intercambios y de las modas. Al mismo tiempo, la transgresión [contida na diferenza] que representaba un desafío a las normas y anunciaba la conquista de nuevos derechos democráticos se banaliza como momento lúdico constitutivo de la subjetividad consumista» (Bensaid, 2004). 
Cando menos podemos distinguir tres. Hai un plano en que funciona como mera palabra descritiva, que remite á diversidade sociocultural, ás súas variadas manifestacións identitarias, mesturas, etc. En moitos casos, cando se fala do multiculturalismo dunha sociedade, dunha cidade ou mesmo dunha empresa, simplemente se fai referencia á diversidade que contén ou quere expresar. Aquí en verdade promóvese unha confusión elemental, co cal se debería, en todo caso, designar como multiculturalidade. Non hai que levar a inxenuidade ata supoñer que en todos os casos unha confusión tan evidente é, así mesmo, inxenua. $\mathrm{O}$ que se pretende é cargar o multiculturalismo con resonancias positivas, identificándoo no imaxinario coa diversidade.

En ocasións aínda se vai máis lonxe, cando se usa como unha especie de categoría política para referirse ás loitas pola diversidade ou ás propostas alternativas dos que loitan, cualificándoas de movementos, demandas ou proxectos multiculturalistas. Aquí insinúase ambiguamente que estes movementos e proxectos se enmarcan nun enfoque particular que se desexa promover e que é o verdadeiro sentido contemporáneo do multiculturalismo. Así, algúns chegaron a afirmar que, hoxe, todos somos multiculturalistas. En rigor, isto está lonxe de ser verdade.

O multiculturalismo aparece no seu real carácter cando lle prestamos atención á súa medula, en canto un peculiar enfoque teórico-político que contén unha concepción do que é a diversidade e como se debe inserir no sistema de dominación; e que, consecuentemente, recomenda un conxunto de prácticas ou políticas públicas que se deben adoptar no tocante ás diferenzas -políticas de identidade-, especialmente polo que fai á devandita neutralidade do Estado en combinación coas chamadas accións afirmativas ou discriminacións positivas, etc. E daquela, a idea de que todos somos ou debemos ser multiculturalistas cae polo seu propio peso. Nos dous primeiros sentidos, o multiculturalismo é un usurpador de realidades que se deberían designar con outros termos, por exemplo: multiculturalidade e resistencia. En realidade, o multiculturalismo que interesa aquí, e o único que existe, é o enfoque teórico-político e as súas prácticas conexas.

Cos seus múltiples rostros benévolos, o multiculturalismo expándese por todo o mundo, incluíndo Latinoamérica, co prestixio que lle outorga a súa defensa da diversidade e a promoción do pluralismo. Pero, en realidade, o multiculturalismo que se impón con singular ímpeto nos últimos anos é un produto netamente liberal, orixinalmente elaborado e empaquetado nos centros de 
pensamento anglosaxóns e cuxas fábricas intelectuais se atopan nalgúns medios académicos de países como os Estados Unidos, Canadá e Inglaterra; posteriormente, desde logo, atopou os seus ideólogos vicariais, epígonos e divulgadores noutras rexións, moitos deles nas maquilladoras intelectuais da periferia.

Para os grupos identitarios, como os pobos indios de América Latina, o multiculturalismo é unha mala mercancía. Nin o seu enfoque nin os arranxos que propón resolven as cuestións centrais -sociais, económicas e políticas- que presenta a diversidade alí e, seguramente, noutras rexións do mundo.

O multiculturalismo ocúpase da diversidade en canto diferenza cultural, mentres que repudia ou deixa de lado as diferenzas económicas e sociopolíticas que, de apareceren, terían como efecto marcar a disparidade respecto do liberalismo que está na súa base. Como o multiculturalismo pretendía ser unha proposta de validez universal, non acepta que o seu sentido liberal se presente como unha solución particular. $\mathrm{O}$ que quere evitar non é tanto que se revele o seu contido eurocéntrico ou dalgunha outra matriz cultural, senón que quede patente que a decisiva particularidade da súa universalidade é a globalización do capital. Finalmente, así examinado, un dos máis pregoados valores do multiculturalismo -a súa pretendida superioridade no tocante á tolerancia- transfórmase no seu contrario, a intolerancia.

Pode o multiculturalismo ser tolerante, crítico e emancipador? Polo visto ata aquí hai que constatar que a tolerancia multiculturalista é intolerante do verdadeiro Outro. En Elogio de la diversidad abordamos con máis detalle os problemas que se lle presentan ao liberalismo para ser consecuentemente tolerante ${ }^{25}$. O multiculturalismo, en canto enfoque liberal, revela nós similares. Como apunta Žižek, o multiculturalismo só é tolerante co Outro cando este deixa de selo, cando perde a medula da súa alteridade. En canto peza do sistema de dominio imperial, o momento multiculturalista non é honradamente pluralista, senón un dispositivo para atraer as identidades ao seo do Imperio, nos termos do novo liberalismo igualitario e político. No mellor dos casos, o multiculturalismo practica un respecto condescendente polos costumes inofensivos. Para os realmente Outros, di Žižek que «la tolerancia es tolerancia cero». É así como podemos ver, descobre o autor, que «esta tolerancia liberal reproduce el fun-

\footnotetext{
25 Ver capítulo II desa obra.
} 
cionamiento elemental posmoderno de acceder al objeto solo en tanto éste está privado de su sustancia: podemos disfrutar café sin cafeína, cerveza sin alcohol, sexo sin contacto corporal -y, en la misma línea, nos llevamos muy bien con el Otro étnico privado de la substancia de su Otredad» (Žižek, 2004, p. 26).

Á luz de todo isto, cabe preguntarse se é preciso ou recomendable manter o multiculturalismo, despois de eliminar as súas partes negativas. É posible concibir un multiculturalismo bo, positivo ou crítico? É de temer que co multiculturalismo aconteza o mesmo que coa teoría e a práctica que coñecemos en Latinoamérica como indixenismo ${ }^{26}$. A experiencia demostrou que non é posible concibir un indixenismo bo, que sexa rescatable para os obxectivos da emancipación dos pobos. A única maneira de protexerse das consecuencias nocivas do indixenismo é negándoo radicalmente, poñéndose á marxe del.

Noutra parte indiquei que o indixenismo non é en modo ningún a solución, senón que é parte do problema que hai que resolver (1988). Así como o indixenismo contén unha gran carga ideolóxico-política, polo que fai á combinación de evolucionismo, culturalismo e funcionalismo que está na súa base, o multiculturalismo está enchido de principios e valores liberais que son o seu núcleo. Descargado de todo isto, que quedaría do multiculturalismo? É difícil ver algunha utilidade en conservar mesmo a palabra, sen que arrastre as súas connotacións máis punzantes. E se lle fose extraída a súa medula condescendente, intolerante, etc., por que teriamos que chamar multiculturalismo ao que quedase en pé, se é que algo quedase? ${ }^{27}$. A alternativa máis prometedora fronte

\footnotetext{
26 Paga a pena aclarar unha vez máis que aquí non estamos a entender indixenismo como noción de sentido común, aplicable aos que defenden os pobos indios ou manifestan aprecio polas súas culturas, etcétera, senón como categoría política que se refire a un enfoque e unha práctica de axentes de poder para rematar co "problema» indíxena. $\mathrm{O}$ indixenismo tradúcese nunha política de Estado. Un teórico orgullosamente indixenista foi quen o dixo sen reservas: «El indigenismo no es una política formulada por indios para la solución de sus propios problemas sino la de los no indios respecto a los grupos étnicos heterogéneos que reciben la general designación de indígenas» (Aguirre Beltrán, 1975, p. 24 e 25). Para unha crítica do indixenismo véxase H. Díaz-Polanco (1987).

${ }^{27}$ Neste punto leva razón Žižek cando argumenta que «si, en contraste con el "multiculturalismo corporativo", definimos un "multiculturalismo crítico", como estrategia para señalar que "hay fuerzas comunes de opresión, estrategias comunes de exclusión, estereotipamiento, y estigmatización de grupos oprimidos, y por lo tanto enemigos y blancos de ataque comunes", entonces no se ve la adecuación del uso continuado del término "multiculturalismo", ya que el acento aquí se ha desplazado hacia la lucha común. En su significado usual, el multiculturalismo encaja perfectamente con la lógica del mercado global» (2004, p. 24 e 25).
} 
ao vello indixenismo e ao novo multiculturalismo é o autonomismo que recoñece no Outro a potencia para vivir ben no mundo.

\section{A POTENCIA EMANCIPADORA DA COMUNIDADE}

A única saída á vista é o dobre movemento de frear e combater a individualización da sociedade que está a xeneralizar a globalización e, así mesmo, promover a construción da comunidade, fundada nas identidades múltiples.

Pero de novo aquí, cando falamos de comunidade, debemos precisar de que conglomerado humano estamos a falar, pois a globalización tamén ten a súa preferencia comunitaria. Bauman completa a súa visión do tipo de comunidade -correspondente á categoría de identidade volátil ou identificación xa examinada- que é propio da actual etapa do capitalismo, fase bautizada por el como «modernidade líquida». No seu seo, hai unha estreita correlación entre as «pseudoidentidades» creadas pola globalización e as novas comunidades procesadas, circunstancial e temporalmente, para substituír os colectivos que sucumben $^{28}$.

Como caracterizar e bautizar estas "pseudocomunidades» ou comunidades globalizadas? $\mathrm{O}$ autor adopta a designación de comunidades de gardarroupa que denota moi apropiadamente as características senlleiras destas unións temporais de individuos. Os asistentes a un espectáculo, vestidos para a ocasión, antes de entrar na sala deixan no gardarroupa os seus abrigos e outras prendas; participan na función cunha vaga ou intensa sensación de ser parte dun conglomerado que aplaude, garda silencio, desaproba ou estoupa de xúbilo ao unísono, galvanizados non pola relación entre eles senón polo evento que os congrega. Cando remata a función, os espectadores recollen as súas roupas, se é o caso, tornan aos seus respectivos roles e volven ser individuos atomizados sen practicamente nada

28 Trátase tamén dunhas "pseudocomunidades extraterritoriais» ou dependentes o menos posible das «restricións territoriais» e que, igual que as identidades da modernidade líquida, "tienden a ser volátiles, transitorias, "monoaspectadas" o "con un solo propósito". Su tiempo de vida es breve y lleno de sonido y de furia. No extraen poder de su expectativa de duración sino, paradójicamente, de su precariedad y de su incierto futuro, de la vigilancia y de la inversión emocional exigida por su frágil pero furibunda existencia» (Bauman, 2003, p. 210). 
en común. O grupo foi disolto. Este tipo de comuninades require o espectáculo como factor aglutinante dos individuos. Pero os diversos espectáculos «como ocasión de existencia de una comunidad de guardarropa, no fusionan los intereses individuales en un interés grupal: esos intereses no adquieren una nueva calidad al agruparse, y la ilusión de situación compartida que proporciona el espectáculo no dura mucho más que la excitación provocada por la representación». Bauman conclúe dicindo que, na actual modernidade líquida, os espectáculos substitúen a causa común que caracterizaba a época da «modernidad pesada/sóli$\mathrm{da} /$ hardware».

Estas agrupacións tamén se poden chamar comunidades de carnaval, pois teñen en común o feito de ser «acontecimientos que quiebran la monotonía de la soledad diaria, y que, como los carnavales, dan canalización a la tensión acumulada, permitiendo que los celebrantes soporten la rutina a la que deben regresar en cuanto acaban los festejos». Convén aclarar que o carnaval, tal e como o define aquí Bauman, debe ser claramente distinguido da festa, que nalgunhas culturas pode adoptar formas carnavalescas ${ }^{29}$.

En cambio, as comunidades de gardarroupa ou de carnaval constitúen «un rasgo tan indispensable del paisaje líquido/moderno como la soledad de los individuos de jure y sus ardientes pero vanos esfuerzos por elevarse al nivel de los individuos de facto». É fácil entender daquela que estas comunidades, eses «artefactos efímeros del continuo juego de la individualidad", como o extracta o autor, non poden ser o remedio para a soidade e o sufrimento dos individuos nin o terreo en que estes poden expresar as súas enerxías socialmente creadoras: «Un efecto de las comunidades de guardarropa/carnaval es impedir la condensación de las "genuinas" (es decir, duraderas y abarcadoras) comunidades a las que imi$\tan$ y a las que (falsamente) prometen reproducir o generar nuevamente. En

\footnotetext{
${ }^{29}$ Como observou agudamente Gadamer, a festa está máis emparentada co rito e o seu espírito colectivo, cuxa natureza radica en «ser sostenido por la totalidad de los reunidos o de sus representantes, todos los cuales se empeñan en el mantenimiento de los usos». A diferenza do espectáculo ou o carnaval, onde os individuos son consumidores efémeros e non logran construír un colectivo que transcenda a repre mediante la música o mediante los discursos solemnes». E as cousas actúan así, mesmo no caso de que «la fiesta no sea ninguna celebración alegre». As festas son «formas de la vida en las que todos se reúnen [...], siempre de modo que el discurrir de los momentos festivos y el cumplimiento de los usos son compartidos por todos» (Gadamer, 1997, p. 92 e 93).
} 
cambio, lo que hacen es dispersar la energía de los impulsos sociales y contribuyen así a la perpetuación de una soledad que busca - desesperada pero vanamente- alivio en los raros emprendimientos colectivos concertados y armoniosos» (Bauman, 2003, p. 211 e 212) ). $^{30}$.

As "pseudocomunidades» da modernidade líquida poden emparentar cos «non lugares» da «sobremodernidade» que estuda Marc Augé. Os non lugares, como os entende este autor, traspasan os momentos de encontro efémero, os espectáculos que configuran as comunidades de gardarroupa, abranguendo territorios cada vez máis amplos da sociedade contemporánea. Non obstante, as sociedades fugaces de gardarroupa poden ser espacialmente situadas no ámbito típico dos non lugares. Os non lugares serían os espazos óptimos nos que se poden desenvolver á perfección aquelas comunidades pasaxeiras.

Como se definen estes non lugares? «Si un lugar puede definirse como lugar de identidad, relacional e histórico, un espacio que no puede definirse ni como espacio de identidad ni como relacional ni como histórico, definirá un no lugar». A «sobremodernidade» é "productora de no lugares, es decir, de espacios que no son en sí lugares antropológicos», senón os espazos da «individualidad solitaria» (Augé, 1998, p. 83).

Desde os aeroportos aos supermercados, desde as cadeas hoteleiras ao illamento do caixeiro automático, a «sobremodernidade» impón «a las conciencias individuales experiencias y pruebas muy nuevas de soledad». Mentres «los lugares antropológicos crean lo social orgánico, los no lugares crean la contractualidad solitaria ${ }^{31}$.

Queda claro que a idea expresada antes -a defensa da comunidade é un factor crucial na presente etapa histórica, quizais como nunca o fora antes- non se

\footnotetext{
${ }^{30}$ De paso, isto debería previrnos contra unha concepción da "promoción cultural», en canto política pública, entendida como mero fomento do espectáculo e o carnaval que se esgota no consumo individualizado.

${ }^{31} \mathrm{O}$ papel do non lugar é crear «la identidad compartida de los pasajeros, de la clientela o de los conductores del domingo». En suma, o característico do non lugar é que "no crea ni identidad singular ni relación, sino soledad y similitud, pues allí no se construye la historia sino que reinan la actualidad y la urgencia del momento presente». Así mesmo, o espazo da sobremodernidade «sólo tiene que ver con individuos (clientes, pasajeros, usuarios, oyentes) pero no están identificados, socializados ni localizados [...] más que a la entrada y a la salida»; o non lugar é «lo contrario de la utopía: existe y no postula ninguna sociedad orgánica», é dicir, é incapaz de construír sociedades sólidas (Augé, 1998, p. 97, 98 e 114).
} 
refire ás «pseudocomunidades» promovidas pola globalización nin aos correspondentes non lugares da «sobremodernidade». Estamos a falar doutra comunidade: aquela colectividade que lles dá sentido duradeiro e profundo aos suxeitos, que se funda en tecidos e nexos sociais con algunha referencia territorial, enraizada nun lugar, e en cuxo ámbito son quen de construír non só identidades sólidas senón ademais proxectos comúns de alcance social. Contra esta comunidade o poder globalizado ten que arremeter con todas as súas forzas ${ }^{32}$.

Cando se pregunta sobre o papel actual da resistencia política no ámbito cultural, que involucra sempre unha defensa da forma de vida propia, Jameson advirte que esta pode promover un poderoso programa negativo capaz de facer evidente "todas las formas visibles e invisibles de imperialismo cultural; permite identificar a un enemigo, visualizar fuerzas destructivas». Deste modo, por exemplo, ao sinalar os fenómenos de destrución e desprazamento da literatura local polos best-sellers das grandes empresas editoriais, da produción cinematográfica nacional pola asoballante competencia de Hollywood, dos espazos de interacción e sociabilidade acostumados, como os cafés e restaurantes, cuxo lugar é ocupado polos negocios transnacionais da fast-food, etc., "pueden verse en primer lugar y de forma más dramática los efectos más profundos e intangibles de la globalización sobre la vida cotidiana».

Pero non é alí onde se atopa toda a fibra da resistencia política, advirte o autor, pois a vida cotiá ameazada é moito máis difícil de representar, dado que, aínda que a súa disgregación se fai visible, decote «la sustancia positiva de lo que se defiende tiende a reducirse a tics y rarezas antropológicas», traducíndose na defensa dalgunha tradición, especialmente relixiosa. Jameson pon en cuestión a noción de tradición, en canto que por si mesma suscita serías dúbidas de que poida proporcionar a forza para estar á altura dos actuais desafíos que encarna o capital globalizado. Esa potencia radica máis ben na propia comunidade (Jameson, 2000, p. 20).

\footnotetext{
32 Bauman di que «cualquier trama densa de nexos sociales, y particularmente una red estrecha con base territorial, implica un obstáculo que debe ser eliminado. Los poderes globales están abocados al desmantelamiento de esas redes, en nombre de una mayor y constante fluidez, que es la fuente principal de su fuerza y la garantía de su invencibilidad. Y el derrumbe, la fragilidad, la vulnerabilidad, la transitoriedad y la precariedad de los vínculos y redes humanos permiten que esos poderes puedan actuar» (2003, p. 20).
} 
En efecto, di Jameson, «la potencia concreta» da resistencia política que pode latexar nunha tradición "no deriva de su sistema de creencias como tal, sino de su anclaje en una comunidad realmente existente». A comunidade, coas reservas que se indicarán logo, convértese así no bastión fundamental da resistencia política positiva e socialmente produtiva ${ }^{33}$.

Pero isto non supón unha defensa conservadora da comunidade. Jameson non ignora que, cando menos desde un enfoque de esquerdas, sería un erro «pensar este programa -la preservación de lo colectivo por encima de y contra lo atomizado y lo individualista- como si se tratara de una variante nostálgica o (literalmente) conservadora». De aí que de inmediato agregue a apostila sobre os tres problemas aos que lle ten que facer fronte quen «apele al valor fundamental de la comunidad o de la colectividad desde una perspectiva de izquierdas», a saber, "cómo distinguir radicalmente esta posición del comunitarismo" (1997, p. 52-55); "cómo diferenciar el proyecto colectivo del fascismo o el nazismo», ou, en xeral, de calquera proxecto autoritario e excluínte; e un punto básico, "cómo poner en relación mutua el ámbito social y el económico» (Jamelson, 2000, p. 21).

Reteño aquí a idea decisiva de que a defensa da comunidade, vital nos nosos días, non implica unha apelación conservadora á tradición. Hoxe non basta con facer a mera apoloxía dos usos e costumes. Giddens expresou un punto de vista semellante cando observou que, aínda que decote é preciso defender a tradición, «ya no podemos defender la tradición de modo tradicional» (1994, p. 20). No caso co ntrario, existe o perigo certo de que a reivindicación da comunidade e da autonomía se converta no cabalo de batalla de novos fundamentalismos,

\footnotetext{
33 «Esta es la razón por la cual, en última instancia, todos los proyectos de resistencia puramente económicos deben acompañarse de un desplazamiento de la atención (que conserve en su seno todos los ámbitos anteriores) de lo económico a lo social [e de alí ao político e ao punto crucial do poder, engado eu]. Las formas preexistentes de cohesión social, aunque no son suficientes por sí mismas, constituyen necesariamente la condición previa indispensable de toda lucha política eficaz y duradera, de todo gran empeño colectivo. Al mismo tiempo, estas formas de cohesión son de suyo el contenido de la lucha, los envites de todo movimiento político, el programa por asi decir de su propio proyecto» (Bauman, 2003, p. 21); as cursivas son nosas. Alí, o autor fai unha puntualización de extraordinaria importancia: «tal cohesión colectiva [fonte e plataforma da resistencia política] puede fraguarse en la lucha»; é dicir, a loita mesma pode ser a fábrica social dun sentido de comunidade que, así mesmo, se volve un referente e unha forza de resistencia.
} 
de novas intolerancias e, en consecuencia, de novos ou vellos autoritarismos. Un autonomismo radical e innovador-que non presume que todas as solucións xa estean dadas na tradición nin alimenta a ilusión de que é posible atopar saídas sectoriais, para un ou outro grupo identitario, mentres se deixa sen tocar o sistema globalizador do capitalismo- ten que asumir responsablemente esa eventualidade.

Sempre haberá riscos de que a defensa da comunidade, como condición dunha loita política emancipadora, se descompoña en crispacións fundamentalistas, pero as posibilidades de evitalas ou neutralizalas serán maiores no marco dunha concepción da comunidade e a autonomía aberta, innovadora e incluínte, que escape do cerco comunalista (1997, punto 7). O que resulta claro é que o camiño para a emancipación non pode ser a individualización que actualmente impulsa a estratexia globalizadora. En calquera caso, os desafíos reais que afrontemos no transo de afirmar a estratexia comunitaria non deben diminuír senón afirmar a convicción de que é na construción da comunidade, en toda a súa extensa gama -desde a localidade, pasando por todas as formas de pertenza sociais, de crenzas, de xénero, etc., ata a comunidade nacional e aínda alén-, onde se atopa unha das claves fundamentais para encarar con éxito as ameazas que implica o réxime do capital globalizador e para abrir o camiño cara a outro mundo posible. 


\section{BibliografíA}

Aguirre Beltrán, G.: «Un postulado de política indigenista», en Obra polémica, México, Cisinah-Sepinah, 1975.

Almeyra, G.: «La multitud y la varita mágica», Memoria, México, CEMOS, n.o 197 (xullo 2005).

AUGÉ, M.: Los no lugares: espacios del anonimato. Una antropología de la sobremodernidad, Barcelona, Editorial Gedisa, 1998.

Bauman, Z.: La sociedad individualizada, Madrid, Ediciones Cátedra, 2001.

Bauman, Z.: Modernidad líquida, Bos Aires, Fondo de Cultura Económica, 2003.

BENSAID, D.: «Teoremas de la resistencia a los tiempos que corren», en Viento Sur, Bos Aires, 2004.

BENSAID, D.: «Multitudes ventrílocuas», Memoria, México, CEMOS, n.o 197 (xullo 2005).

Borón, A.: Imperio \& imperialismo. Una lectura critica de Michael Hardt y Antonio Negri, Bos Aires, CLACSO, 2002.

Borón, A.: «El imperio y la teoría marxista del imperialismo», Memoria, México, CEMOS, n. ${ }^{\circ} 184$ (xuño 2004).

Cerletti, J. L.: «Multitud: la emancipación según Antonio Negri y Michael Hardt», Memoria, México, CEMOS, n.o 197 (xullo 2005).

DíAZ-POLANCO, H.: «La teoría indigenista y la integración», en Indigenismo, modernización y marginalidad. Una revisión crítica, México, 1987.

DíaZ-Polanco, H.: La cuestión étnico-nacional, México, Fontamara, 1988.

DíAZ-POlAnCO, H.: Autonomía regional. La autodeterminación de los pueblos indios, México, Siglo XXI Editores, 1991.

Díaz-POLANCO, H.: La rebelión zapatista y la autonomía, México, Siglo XXI Editores, 1997.

DíAZ-POLANCO, H.: "La realidad es más que una inmensa estepa verde. Siete precisiones necesarias», Ojarasca, México, n. ${ }^{\circ} 6$ (outubro 1997).

Díaz-Polanco, H.: Elogio de la diversidad, México, Siglo XXI Editores, 2006.

Eagleton, T.: Después de la teoría, Barcelona, Debate, tradución de R. García Pérez, 2005.

Gadamer, H. G.: «Acerca de la fenomenología del ritual y el lenguaje», en Mito y razón, Barcelona, Paidós, 1997.

GEERTZ, C.: Reflexiones antropológicas sobre temas filosóficos, Barcelona, Paidós, 2002.

GidDEns, A.: Más allá de la izquierda y la derecha. El futuro de las políticas radicales, Madrid, Cátedra, 1994.

GIDDENS, A.: La tercera vía. La renovación de la socialdemocracia, Madrid, Taurus, 1999.

GonzÁlez Casanova, P.: "Colonialismo interno (Una redefinición)», Rebeldía, México, n.o 12 (outubro 2003).

GRAY, J.: Las dos caras del liberalismo. Una nueva interpretación de la tolerancia liberal, Barcelona, Paidós, 2001. Hardt, M. e A. Negri: Imperio, Bos Aires, Paidós, 2002.

Hardt, M. e A. Negri: Multitud. Guerra y democracia en la era del Imperio, Barcelona, Debate, 2004.

JAMESON, F.: “Globalización y estrategia política», New Left Review, Madrid, Ediciones Akal, n. ${ }^{\circ} 5$ (2000).

JAMESON, F.: Una modernidad singular. Ensayo sobre la ontología del presente, Barcelona, Editorial Gedisa, tradución de Horacio Pons, 2004.

Negri, A. e D. ZOLO: «El Imperio y la Multitud. Un diálogo sobre el nuevo orden de la globalización», en Red Voltaire y Rebelión, tradución de Eduardo Sadier, 2003. 
PATZI, F.: «Etnofagia estatal. Modernas formas de violencia simbólica (una aproximación al análisis de la Reforma Educativa», Bulletin de l'Institut Français d'Études Andines, París, 28, 3 (1999).

Petras, J.: «Negri y Hardt: Teoría sin realidad», Clarín, Bos Aires, tradución de J. Ibarburu, 2004.

Programa de Naciones Unidas para el Desarrollo: Las Regiones Autónomas de la Costa Caribe. Informe de Desarrollo Humano 2005, Managua, PNUD, 2005.

Rawls, J.: Teoría de la justicia, México, Fondo de Cultura Económica, tradución de María Dolores González, 1995.

RaWLs, J.: El liberalismo politico, México, Fondo de Cultura Económica, 1995.

SARtori, G.: La sociedad multiétnica. Pluralismo, multiculturalismo y extranjeros, Madrid, Taurus, 2001.

SAXe-Fernández, J. (coord.): Globalización: crítica a un paradigma, México, Plaza y Janés-UnAm-IIES 1999.

SaXe-Fernández, J. e J. Petras: Globalización, imperialismo y clase social, Bos Aires/México, Editorial Lumen, 2001.

Solo de Zaldívar, V.: «Capital social, etnicidad y desarrollo: algunas consideraciones críticas desde los andes ecuatorianos», Yachaikuna, Quito, Instituto Científico de Culturas Indígenas, n. 2 (decembro 2001).

Solo de Zaldívar, V.: «Capital social, etnicidad y desarrollo en los andes ecuatorianos», Memoria, México, CEMOS, n. ${ }^{0} 166$ (decembro 2002).

VILAS, C.: «Seis ideas falsas sobre la globalización. Argumentos desde América Latina para refutar una ideología», en J. SAXE-FeRnÁNDEZ (coord.): Globalización: crítica a un paradigma, México, UNAM/IIEC/DGAPA/Plaza y Janés, 1999.

WALLERSTEIN, I.: Utopistica o las opciones históricas del siglo XXI, México, Ciich e Siglo XXI Editores, 1998.

Wolf, E.: «Tipos de campesinado latinoamericano: una discusión preliminar», en E. R. Wolf: Una tipología del campesinado latinoamericano, Bos Aires, Ediciones Nueva Visión, 1977.

ŽIŽEK, S.: «Multiculturalismo o la lógica cultural del capitalismo multinacional», en F. JAMESON e S. ŽIŽEK: Estudios culturales. Reflexiones sobre el multiculturalismo, Bos Aires, Paidós, introdución de Eduardo Grüner, 1998.

ŽIŽEK, S.: A propósito de Lenin. Politica y subjetividad en el capitalismo tardio, Bos Aires, Atuel/Parusía, prólogo e tradución de S. Waingarten, 2004. 